\title{
Aikuiskoulutuksen kehittämisestä
}

Aikuiskasvatus -lehden edustajat ovat kääntyneet puoleeni pyynnöllä, että arvioisin maamme aikuiskoulutuksen kehitystä ja tilaa sekä tulevaisuuden kehitysnäkymiä. Pyynnön taustana on Aikuiskoulutusneuvoston asettaminen ja työn käynnistyminen. Tulinhan nimetyksi neuvoston yhdeksi jäseneksi ja sittemmin sen varapuheenjohtajaksi. Kun suostuin pyyntöön, lähtökohtanani oli, että kirjoitan pelkästään omissa nimissäni ja omista näkemyksistäni. Aikuiskoulutusneuvoston työ on niin alullaan, etteivät edes toiminnan peruslinjat ole ehtineet asettua paikoilleen. Näin ollen kirjoituksessani olevat kannanotot ovat puhtaasti henkilökohtaisia.

Aikuiskoulutuksen kehittämistä harjoitetaan maassamme monella eri tasolla. Aikuiskoulutukselle on tunnusomaista, että toiminnan suunnittelu ja organisointi tapahtuu aikuiskoulutusinstituutioiden itsensä toimesta. Näin ollen myös toiminnan kehittämisen ylivoimaisesti tärkein osa tapahtuu aikuiskoulutusinstituutioiden sisällä. Koulutusinstituutioiden ohella mielenkiintoa aikuiskoulutuksen kehittämiseen ovat tunteneet mm. työmarkkinajärjestöt, poliittiset puolueet, erilaiset muut yhteisöt sekä kunnat ja valtio. Näistä valtio on harjoittanut systemaattista aikuiskoulutuksen suunnittelua ja kehittämistä jo noin 15 vuoden ajan.

Kun kehittämisen ehdoton painopiste on itse toiminnasta vastaavissa aikuiskoulutusinstituutioissa, ydinkysymys nähdäkseni on, millainen toimintailmasto aikuiskoulutusinstituutioissa tällä hetkellä vallitsee. Missä määrin toimintailmastolle on ominaista uudistumis- ja kehittymishakuisuus, ja missä määrin toiminnan uudistamista ja kehittymistä niissä tapahtuu? Henkilökohtaisesti tunnen tilannetta läheltä vain ammatillista lisäkoulutusta antavissa koulutusinstituutioissa. Nähdäkseni niissä toimintailmasto on varsin hyvä. Voimakkaasta uudistumisesta kertoo mm. lisäkoulutuspalvelujen jatkuva laajeneminen ja lisääntyminen.
Sen tuloksena aikuisten mahdollisuudet oman ammattitaitonsa ylläpitämiseen ja kehittämiseen ovat merkittävästi parantuneet. Niinpä aikuisten osallistuminen ammatilliseen lisäkoulutukseen kasvoi voimakkaasti 1970-luvulla, ja on nähdäkseni edelleen kasvanut 1980-luvulla.

Myös laadullisesti toiminta on merkittävästi kehittynyt. Laadulliselle kehittämiselle antoi tärkeän sysäyksen 1970-luvun loppupuolen heikko taloudellinen tilanne, joka pakotti aikuiskoulutusinstituutiot kehittämään uusia toimintastrategioita sekä jatkuvasti kohottamaan toimintansa laatua. Uskoakseni tuolloin vauhdittunut oman toiminnan laadun parantaminen jatkuu edelleen.

Koulutusinstituutiokohtainen toiminnan kehittäminen on aikuiskoulutuksen kehittämisen ydinkysymys. Vaikka ammatillisessa aikuiskoulutuksessa tilanne onkin nähdäkseni hyvä, myös monia puutteita ja ongelmia esiintyy. Yksi tärkeä kysymys on, että kehittämistyö on koulutusinstituutioille itselleen varsin paljon resursseja vaativaa toimintaa. Monet kehittämishankkeet - mikäli ne haluttaisiin viedä todella 'loppuun saakka' - vaatisivat niin suuren kehittämispanostuksen, ettei yhdellä koulutusinstituutiolla ole siihen yksinään edellytyksiä.

Kun ajatellaan ammatillisen aikuiskoulutuksen kehittämistä yksittäisen koulutusinstituution näkökulmasta, voidaan löytää mm. seuraavia ongelmia:

- Aikuiskasvatuksen teoria, sen pedagogiikka ja didaktiikka, ovat varsin vähän kehittyneet. Monessa kehittämishankkeessa kukin koulutusinstituutio joutuu luomaan 'teorian' viitekehyksineen ja keskeisine käsitteineen itse. Maamme koulutustutkimus on tähän saakka ollut hyvin vähän kiinnostunut aikuiskasvatuksesta ja sen kehittämisestä. Nyt on näkyvissä eräitä merkkejä siitä, että mielenkiintoa voisi olla syntymässä. Yhteistyötä tutkimus- ja koulutusinstituutioden kesken tarvittaisiin nykyistä huomattavasti enemmän. Tutkimusinstituuti- 
oilta tämä edellyttäisi kiinteitä kontakteja käytännön toimintaan. Koulutusintituutioilta se puolestaan edellyttäisi tutkimuksellista asennoitumista ja työskentelyotetta.

- Eräiden tärkeiden koulutusstrategioiden edistäminen vaatisi erityisen paljon laajaa yhteistyötä. Yksi tällainen on monimuotoja etäisopetuksen voimakas lisääminen ja laadullinen kehittäminen. Eräs ydinkysymys on todella laadukkaan ja ajan tasalla olevan oppimateriaalin aikaansaaminen ja ylläpitäminen. Kyse ei ole pelkästään kirjallisesta oppimateriaalista - vaikka se onkin erittäin tärkeä osa - vaan myös av-materiaalista samoin kuin tietokonepohjaisista opetusohjelmista.

Pelkästään yhtä koulutusinstituutiota hyödyttävät ratkaisut tulevat usein kohtuuttoman kalliiksi ja materiaalin laatu jää usein heikommaksi kuin laajaan yhteiskäyttöön pohjautuvilla ratkaisuilla olisi mahdollista aikaansaada. Tässä verotuskysymykset voivat tulla järkevän ja rationaalisen yhteistyön esteeksi.

- Valtionapujärjestelmät ammatillisessa aikuiskoulutuksessa on rakennettu nuorisoasteen koulutuksen pohjalta. Sen vuoksi ne erittäin puutteellisesti ottavat huomioon aikuiskoulutuksen vaatimukset ja erityisluonteen. Toiminnan kehittämisen kannalta puutteet ovat todella suuret. Tähänastiset valtionapukäytännöt ovat jättäneet tuen ulkopuolelle toiminnan suunnittelun ja kehittämisen, kouluttajien koulutuksen jne. Muotosidonnaisuudet ovat puolestaan rajanneet tuen ulkopuolelle muut kuin lähiopetukseen perustuvat ratkaisut.

- Kouluttajien koulutus on ammatillisessa lisäkoulutuksessa ollut järjestettävä koulutusinstituutiokohtaisesti. Tämä koskee sekä perusammattitaidon luomista että ammattitaidon ylläpitoa ja jatkuvaa kehittämistä. Eräiden lisäkoulutusinstituutioiden kesken on syntynyt spontaania yhteistoimintaa kouluttajakoulutuksessa. Tämä on hyvin ymmärrettävää, onhan kyseessä jokaisen koulutusinstituution kannalta todella elintärkeä asia. Laajempi, organisoitu yhteistyö sekä yliopistojen ja korkeakoulujen kytkeminen yhteistoimintaan olisivat tulevaisuuden kannalta erittäin tärkeitä.

- Aikuiskoulutus on nopeasti uudistuvaa ja kehittävää toimintaa. Kehityksen seuraaminen ja ajan tasalla pysyminen on jokaiselle koulutusinstituutiolle yksi avainkysymys. Tämä edellyttää maailmanlaajuista kehityksen seuraamista, uusien ideain ja in- novaatioiden 'löytämistä' sekä niiden arviointia ja muokkaamista omaan toimintaan soveltuvaksi. Tälläkin alueella yhteistyö tuottaisi huomattavasti paremman tuloksen kuin pelkästään yksittäisten koulutusinstituutioiden omat toimenpiteet.

On siis paljon ja todella strategisen tärkeitä alueita, joissa pelkästään koulutusinstituutiopohjaiset ratkaisut eivät anna parasta mahdollista lopputulosta. Sen vuoksi on ollut ilahduttavaa, että valtio on panostanut voimakkaasti aikuiskoulutuksen kehittämissuunnitteluun. Miten sitten valtion harjoittamaa suunnittelua on arvioitava koulutusinstituutiokohtaisen kehittämissuunnittelun näkökulmasta?

Nähdäkseni valtion suunnittelutyön rooli ja funktio ovat tarkoituksenmukaiset ja järkevät. Valtion suunnittelu- ja kehittämistyö ei ole ollut koulutuksen suunnittelua ja kehittämistä, vaan koulutuksen puitteiden luomista ja parantamista. Itse koulutuksen suunnittelu on koulutusinstituutioiden, ei valtion asia.

Valtion aikuiskoulutussuunnittelussa erottuu kolme eri vaihetta, joilla kullakin on oma funktionsa. Ensimmäisen vaiheen muodosti aikuiskoulutuskomitean työ, jonka tehtävänä oli selvittää, mistä aikuiskoulutuksen kehittämisessä on kysymys, sekä osoittaa kehittämistyön yleiset suuntaviivat. Ensimmäinen vaihe päättyi aikuiskoulutuksen merkittävään poliittiseen voittoon: valtioneuvoston päätökseen aikuiskoulutuksen suunnittelu- ja kehittämisperiaatteista. Valtioneuvoston periaatepäätös rakentui aikuiskoulutuskomitean työlle. Ensimmäisessä vaiheessa aikuiskoulutusnäkemys rajautui aikuiskouluttajiin itseensä sekä muutamaan strategisesti tärkeään virkamieheen ja poliitikkoon. Pääosalle virkamiehistä ja poliitikoista aikuiskoulutus oli jotakin kummallista ja käsittämätöntä toimintaa, jolla ei 'oikean' koulutuksen kanssa ollut juuri mitään tekemistä.

Toisen vaiheen muodosti aikuiskoulutuksen väliaikaisen kehittämisorganisaation työ. Toinen vaihe konkretisoi aikuiskoulutuksen kehittämistavoitteet. Toisen vaiheen aikana on jo toteutettu lainsäädännöllisiä ja muita uudistuksia. Parhaillaan on meneillään useita tärkeitä lainsäädännöllisiä hankkeita, jotka koskevat ammatillisen aikuiskoulutuksen toimintapuitteita ja -edellytyksiä. Myös vapaan sivistystyön puolella on vastaavankaltaisia uudistushankkeita. Parhaillaan työtään lopettava aikuiskoulutuksen johtoryhmä on luetteloinut ne uudistukset, jotka tulisi toteuttaa hyvin lyhyen ajan kuluessa. Uudistusluettelo on mittava ja kattaa aikuiskoulutuksen koko kentän. 
Toisen vaiheen aikana aikuiskoulutusnäkemys on muuten ilahduttavasti laajentunut sekä opetusviranomaisten että poliitikkojen keskuudessa. Sekään ei enää tunnu aivan utopistiselta, että aikuiskoulutus nähtäisiin Unescon kirjan 'Learning to be' mukaisesti koulutusjärjestelmän kulminaationa, huippuna, ja että sitä mm. resurssoinnissa kohdeltaisiin sen mukaisesti.

Kolmas vaihe on vasta alkamassa. Nyt valtion harjoittaman aikuiskoulutuksen kehittämistyön painopiste on siirtymässä linjahallinnon ulkopuolisilta elimiltä linjahallinnolle itselleen. Aikuiskoulutusneuvoston rooli on ymmärtääkseni painotetusti avustava, ei ohjaava.

Nähtäväksi jää, millä tavalla linjahallinto nykyisine voimavaroineen kykenee kantamaan vastuunsa aikuiskoulutuksen toimintapuitteiden parantajana ja toiminnan laadun kohottamisen edistäjänä. Ammatillisen aikuiskoulutuksen puolella on nähdäkseni akuutti resurssivaje, jonka poistaminen on edellytyksenä laadukkaalle toiminnalle. Valtionhallinnon voimavarojen tulisi mielestäni laadullisesti olla esimerkilliset, ja valtionhallinnossa työskentelevien tulisi ymmärtää käytännön toiminnan edellytykset ja vaatimukset mahdollisimman hyvin. Tämä edellyttää riittävän laaja-alaista ja monipuolista henkilökohtaista työkokemusta aikuiskoulutuksen käytännön työssä.

Aikuiskoulutusneuvosto voi avustavasta roolistaan huolimatta voimakkaasti vaikuttaa aikuiskoulutuksen kehittämiseen. Kyse on nähdäkseni kahden tyyppisten asiain käsittelystä ja edistämisestä:

- Kulloinkin ajankohtaisten konkreettisten uudistushankkeiden esiintuonti ja tärkeiden uudistusten esiinnostaminen sekä sen varmistaminen, että nämä hankkeet menevät ripeästi eteenpäin. Yhtenä esimerkkinä tällaisesta on vaikkapa etäisopetuksen valtionavun saattaminen yhdenvertaiseen asemaan lähiopetuksen valtionavun kanssa ja valtionavun ulottaminen myös yleissivistävään opetukseen.

- Suurten, pitkävaikutteisten kehittämisalu- eiden esiinnostaminen, niiden kehittämistarpeiden konkretisointi ja tarvittavien kehittämistoimenpiteiden täsmentäminen. Tällaisia suuria kysymyksiä ovat esimerkiksi sellaiset aikuiskoulutuksen laadun parantamiseen liittyvät seikat kuin aikuiskoulutuksen tutkimus ja kokeilu, aikuiskouluttajien koulutus, monimuoto- ja etäisopetuksen lisääminen ja kehittäminen jne.

Aikuiskoulutusneuvoston toimintaedellytyksiä parantaa aikuiskoulutusnäkemyksen ulottuminen yhä laajempaan osaan virkamiesja poliitikkokunnasta. Tässä suhteessa tilanne on todella ratkaisevasti erilainen kuin 1970luvulla. Silti aikuiskoulutuksen kehittämisen lisäresurssit eivät tule itsestään vaan niiden puolesta on tehtävä lujasti työtä kuten tähänkin asti.

Itse korostan Aikuiskoulutusneuvoston roolia aikuiskoulutusinstituutioiden konkreettisten toimintaedellytysten parantajana. Näen, että neuvosto voi ja sen tulee edistää $\mathrm{mm}$. kaikkien niiden ongelmien järkevää ratkaisua, jotka edellä kuvasin yksittäisen aikuiskoulutusintituution oman kehittämistoiminnan esteinä ja rajoituksina. Henkilökohtaisesti tulen vaikuttamaan siten, että juuri tällaiset ongelmat olisivat neuvoston päähuomion kohteena.

Valitan, että olen kirjoituksessani hyvin vähän käsitellyt vapaan sivistystyön ongelmia. Syynä on se, että en tunne niitä yhtä läheltä kuin ammatillisen aikuiskoulutuksen ongelmia, jotka kohtaan joka päivä työssäni. Luulisin kuitenkin, että kehittämisen tarvetta on myös vapaassa sivistystyössä. Ovathan monet rajut yhteiskunnan muutokset luoneet voimakkaita muutos- ja kehittämispaineita esimerkiksi monille kansanopistoille ja opintokeskuksille. Ongelmat ovat usein luonteeltaan strategisia. Muutoksiin ja haasteisiin vastaamatta jättäminen johtaa helposti strategiseen loukkuun, josta poispääsy voi olla hankalaa. Uskoisin, että neuvosto voi olla tärkeä foorumi myös vapaan sivistystyön tärkeiden yhteisten uudistus- ja kehittämishankkeiden esiinnostamiseksi ja edistämiseksi. 